\title{
EDITORIAL
}

\section{Should all septic patients be given systemic anticoagulation? No}

\author{
Tom van der Poll ${ }^{1 *}$ and Steven M. Opal ${ }^{2}$
}

According to current guidelines [1], all patients who are admitted to the intensive care unit (ICU) with sepsis/ septic shock should receive some form of anticoagulant prophylaxis to decrease the risk of deep venous thrombosis and venous thromboembolism (VTE). This VTE prophylaxis usually comes in the form of low dose, systemic anticoagulation to prevent new thrombus formation. Such a dosing strategy is generally applied with unfractionated or low molecular weight heparin, supplemented with venous intermittent compression devices when feasible, or replaced by injectable direct thrombin inhibitors if heparin-induced thrombocytopenia develops. A new generation of oral direct inhibitors of factor Xa or thrombin are now available as VTE preventive agents [2]. Experience of these agents in septic patients is limited and will need to be carefully studied to determine if they could be a new alternative to existing methods of coagulation inhibition. Low dose heparin is intended to prevent new thrombus formation without necessarily clearing existing intravascular clots. High dose therapeutic levels of heparin are needed to clear thrombi but add an attendant risk of causing excess bleeding.

Septic patients almost invariably have some laboratory evidence of activation of the clotting system and would therefore seem to be candidates for anticoagulation to prevent VTE. However, there are several reasons not to administer anticoagulants to all patients with sepsis. First, the evidence in support of VTE prophylaxis is primarily based upon clinical studies of general critical care patients rather than specific studies in sepsis patients

\footnotetext{
*Correspondence: t.vanderpoll@amc.uva.nl

${ }^{1}$ Academic Medical Centre, Center for Experimental and Molecular Medicine and the Division of Infectious Diseases, University of Amsterdam, Meibergdreef 9, G2-130, 1105 AZ Amsterdam, The Netherlands

Full author information is available at the end of the article
}

For a contrasting viewpoint, please go to doi:10.1007/s00134-016-4621-z. only [1]. Second, sepsis patients can suffer from severe coagulopathy associated with bleeding due to consumption of clotting factors and platelets [3]. Indeed, in the placebo groups of large phase 3 trials evaluating systemic anticoagulant therapy for the treatment of sepsis, serious bleeding was reported in 1.0-6.3\% (Table 1) [4-8]. In a recent trial with hydroxyethyl starch for severe sepsis, the incidence of bleeding in the control group was 15\% with severe bleeding found to be as high as 6.3\% [8]. The real incidence of bleeding in the general sepsis ICU population likely is higher considering that anticoagulant trials exclude patients at high risk of bleeding. As such, sepsis patients with evident coagulopathy and/or thrombocytopenia clearly have a contraindication for anticoagulant therapy, as also acknowledged in the Surviving Sepsis guidelines [1].

Third, anticoagulant therapy may impair host defense against nosocomial pathogens in a population that already is vulnerable to secondary infections $[9,10]$. The risk of secondary infection in ICU patients with sepsis varies between 13 and $42 \%$ in some studies and accounts for some of the late fatalities from sepsis [11, 12]. The innate immune system and the hemostatic system coevolved and continue to function in concert to protect the host from invasive microorganisms [10]. Indeed, activation of coagulation elicits immune defense machineries at a very early stage of microbial invasion, which include the release of antimicrobial peptides, recruitment and activation of phagocytizing cells, and induction of innate immune responses through activation of protease-activated receptors. The term immunothrombosis is now used to highlight the essential co-dependency of the coagulation and innate immune systems [13]. This collaboration between innate immunity and clotting evolved to recognize breaches in the integument early on and wall off and eradicate microbial invaders before they threaten host survival. In accordance, there

\section{Springer}


Table 1 Incidence of bleeding in placebo groups of large phase 3 sepsis trials with anticoagulants

\begin{tabular}{llll} 
Population & Non-serious bleeding (\%) & Serious bleeding (\%) & References \\
\hline Septic shock & 4.8 & 1.0 & {$[4]$} \\
Severe sepsis & $\mathrm{NL}$ & 2.0 & {$[5]$} \\
Severe sepsis, INR $<1.2$ & 21.0 & 3.3 & {$[6]$} \\
Severe sepsis, INR $\geq 1.2$ & 19.0 & 4.8 & {$[6]$} \\
Severe sepsis & 12.8 & 5.7 & {$[7]$} \\
Severe sepsis & 15.0 & 6.3 & {$[8]$} \\
\hline
\end{tabular}

NL not listed

are numerous examples in the animal laboratory where inhibitors of elements of the coagulation system impair microbial clearance and increase mortality during experimental infections [10]. It is at least theoretically possible that efforts to protect patients from VTE might put them at increased risk for secondary infection.

An example of where perturbations in clotting mechanisms in humans alter infection risk is provided by the clinical experience with factor $\mathrm{V}$ Leiden (FVL) and activated protein $C$ (APC) trials in sepsis. It was assumed that this common polymorphism in European populations (4-6\% carry one allele) would not benefit from APC as the active site for APC on factor V was altered (Arg506Gln) and this prevents factor V degradation by APC. Remarkably, in the first phase 3 trial, FVL heterozygotes randomized to the placebo group had a statistically better outcome than patients without FVL (13.9 vs. $27.9 \%$; $p<0.05$ ) [14]. This finding was recapitulated in genetically modified mice indicating that excess clotting risk with FVL was a balanced polymorphism accompanied by reduced risk of death from sepsis. Although subsequent genetic association studies have been inconsistent as to the protection of infection risk afforded by FVL [15], at this point in our understanding caution is warranted with regard to inhibiting coagulation in all patients with sepsis.

In conclusion, with the lack of large randomized controlled clinical trials in sepsis patients showing any benefit, the increased bleeding risk of a large subset of patients with sepsis, and the possibility that anticoagulants can hamper coagulation-assisted clearance of pathogens, universal use of anticoagulation in these patients cannot be recommended.

\footnotetext{
Author details

${ }^{1}$ Academic Medical Centre, Center for Experimental and Molecular Medicine and the Division of Infectious Diseases, University of Amsterdam, Meibergdreef 9, G2-130, 1105 AZ Amsterdam, The Netherlands. ${ }^{2}$ Infectious Disease Division, Warren Alpert Medical School of Brown University, Providence, Rl, USA.
}

\section{Compliance with ethical standards}

Conflicts of interest

The authors report no conflicts of interest.
Received: 17 October 2016 Accepted: 20 October 2016

Published online: 13 February 2017

References

1. Dellinger RP, Levy MM, Rhodes A, Annane D, Gerlach H, Opal SM, Sevransky JE, Sprung CL, Douglas IS, Jaeschke R, Osborn TM, Nunnally ME, Townsend SR, Reinhart K, Kleinpell RM, Angus DC, Deutschman CS, Machado FR, Rubenfeld GD, Webb S, Beale RJ, Vincent JL, Moreno R, Surviving Sepsis Campaign Guidelines Committee including The Pediatric Subgroup (2012) Surviving Sepsis Campaign: international guidelines for management of severe sepsis and septic shock, 2012. Intensive Care Med 39(2):165-228

2. Kazmi RS, Lwaleed BA (2011) New anticoagulants: how to deal with treatment failure and bleeding complications. Br J Clin Pharmacol 72(4):593-603

3. Levi M, van der Poll T (2010) Inflammation and coagulation. Crit Care Med 38(2 Suppl):S26-S34

4. Ranieri VM, Thompson BT, Barie PS, Dhainaut JF, Douglas IS, Finfer S, Gardlund B, Marshall JC, Rhodes A, Artigas A, Payen D, Tenhunen J, Al-Khalidi HR, Thompson V, Janes J, Macias WL, Vangerow B, Williams MD (2012) Drotrecogin alfa (activated) in adults with septic shock. N Engl J Med 366(22):2055-2064

5. Bernard GR, Vincent JL, Laterre PF, LaRosa SP, Dhainaut JF, Lopez-Rodriguez A, Steingrub JS, Garber GE, Helterbrand JD, Ely EW, Fisher CJ Jr (2001) Efficacy and safety of recombinant human activated protein $C$ for severe sepsis. N Engl J Med 344(10):699-709

6. Abraham E, Reinhart K, Opal S, Demeyer I, Doig C, Rodriguez AL, Beale R, Svoboda P, Laterre PF, Simon S, Light B, Spapen H, Stone J, Seibert A, Peckelsen C, De Deyne C, Postier R, Pettila V, Artigas A, Percell SR, Shu V, Zwingelstein C, Tobias J, Poole L, Stolzenbach JC, Creasey AA (2003) Efficacy and safety of tifacogin (recombinant tissue factor pathway inhibitor) in severe sepsis: a randomized controlled trial. JAMA 290(2):238-247

7. Warren BL, Eid A, Singer P, Pillay SS, Carl P, Novak I, Chalupa P, Atherstone A, Penzes I, Kubler A, Knaub S, Keinecke HO, Heinrichs H, Schindel F, Juers M, Bone RC, Opal SM (2001) Caring for the critically ill patient. High-dose antithrombin III in severe sepsis: a randomized controlled trial. JAMA 286(15):1869-1878

8. Haase N, Wetterslev J, Winkel P, Perner A (2013) Bleeding and the risk of death with hydroxyethyl starch in severe sepsis: post hoc analyses of a randomized clinical trial. Intensive Care Med 39:2126-2134. doi:10.1007/ s00134-013-3111-9

9. Hotchkiss RS, Monneret G, Payen D (2013) Sepsis-induced immunosuppression: from cellular dysfunctions to immunotherapy. Nat Rev Immunol 13(12):862-874

10. van der Poll T, Herwald $H$ (2014) The coagulation system and its function in early immune defense. Thromb Haemost 112(4):640-648

11. Vincent $J L$ (2003) Nosocomial infections in adult intensive-care units. Lancet 361(9374):2068-2077

12. van Vught LA, Klein Klouwenberg PM, Spitoni C, Scicluna BP, Wiewel MA, Horn J, Schultz MJ, Nurnberg P, Bonten MJ, Cremer OL, van der Poll T, MARS Consortium (2016) Incidence, risk factors, and attributable mortality of secondary infections in the intensive care unit after admission for sepsis. JAMA 315(14):1469-1479 
13. Engelmann B, Massberg S (2013) Thrombosis as an intravascular effector of innate immunity. Nat Rev Immunol 13(1):34-45

14. Kerlin BA, Yan SB, Isermann BH, Brandt JT, Sood R, Basson BR, Joyce DE, Weiler H, Dhainaut JF (2003) Survival advantage associated with heterozygous factor $V$ Leiden mutation in patients with severe sepsis and in mouse endotoxemia. Blood 102(9):3085-3092
15. Levi M, Schouten $M$, van't Veer $C$, van der Poll T (2011) Factor V Leiden mutation in severe infection and sepsis. Semin Thromb Hemost 37(8):955-960 